Microcomputer Fault-finding and Design 
Other Macmillan titles for engineers

B. W. Allen, Analogue Electronics for Higher Studies

B. R. Bannister and D. G. Whitehead, Fundamentals of Modern Digital Systems, second edition

J. D. Edwards, Electrical Machines and Drives

A. B. Fontaine and F. Barrand, 80286 and 80386 Microprocessors - New $P C$ architectures

M. E. Goodge, Analog Electronics

B. A. Gregory, An Introduction to Electrical Instrumentation and Measurement Systems, second edition

P. Jaulent, L. Baticle and P. Pillot, 68020/68030 Microprocessors and their Coprocessors

R. J. Mitchell, Microcomputer Systems - An Introduction

R. J. Mitchell, Microcomputer Systems Using the STE Bus

M. S. Nixon, Introducing Digital Design

L. A. A. Warnes, Electronic and Electrical Engineering 


\section{Microcomputer \\ Fault-finding and Design}

\section{Robin Holland}

Principal Lecturer at Swansea

Institute of Higher Education

Second Edition

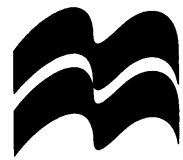


(C) R. C. Holland 1991, 1995

All rights reserved. No reproduction, copy or transmission of this publication may be made without written permission.

No paragraph of this publication may be reproduced, copied or transmitted save with written permission or in accordance with the provisions of the Copyright, Designs and Patents Act 1988, or under the terms of any licence permitting limited copying issued by the Copyright Licensing Agency, 90 Tottenham Court Road, London W1P 9HE.

Any person who does any unauthorised act in relation to this publication may be liable to criminal prosecution and civil claims for damages.

First edition 1991

Second edition 1995

Published by

MACMILLAN PRESS LTD

Houndmills, Basingstoke, Hampshire RG21 2XS

and London

Companies and representatives

throughout the world

ISBN 978-0-333-64166-8

ISBN 978-1-349-13808-1 (eBook)

DOI 10.1007/978-1-349-13808-1

A catalogue record for this book is available from the British Library.

$\begin{array}{llllllllll}10 & 9 & 8 & 7 & 6 & 5 & 4 & 3 & 2 & 1\end{array}$

$\begin{array}{rrrrrrrrrr}04 & 03 & 02 & 01 & 00 & 99 & 98 & 97 & 96 & 95\end{array}$ 


\section{Contents}

Preface $\quad$ ix

Acknowledgements $\quad$ xi

1 Microcomputer Architecture 1

1.1 Generalised microcomputer construction 1

1.2 Program execution by the CPU 2

$\begin{array}{ll}1.3 \text { Address decoding } & 7\end{array}$

1.4 Memory ICs 11

1.5 Input/output ICs 13

$\begin{array}{ll}1.6 \text { Stack } & 17\end{array}$

1.7 Co-processors 18

Bibliography $\quad 19$

2 Testing an Unresponsive Computer 20

2.1 Introduction 20

2.2 Power supply checks $\quad 20$

2.3 Initial CRO checks 23

2.4 NOP (No-operation) test 26

2.5 Static stimulus testing $\quad 30$

2.6 Debug EPROM 35

2.7 Miscellaneous factors $\quad 37$

Bibliography $\quad 39$

3 Board Testing $\quad 40$

3.1 Logic probe, logic pulser and current tracer 40

3.2 Logic monitor and logic comparator $\quad 45$

3.3 Computer-based IC testers $\quad 46$

Bibliography $\quad 49$

4 Diagnostic Software $\quad 50$

4.1 Introduction $\quad 50$

4.2 Start-up ROM 51

4.3 Monitor ROM 52

4.4 Entered test programs 53

Bibliography $\quad 62$ 
$5 \quad$ Peripheral Testing $\quad 63$

5.1 Introduction $\quad 63$

5.2 VDUs and serial devices $\quad 63$

5.3 Parallel printers $\quad 68$

$\begin{array}{ll}5.4 \text { Floppy disks } & 71\end{array}$

5.5 Audio cassette recorders $\quad 75$

$\begin{array}{ll}\text { Bibliography } & 78\end{array}$

6 Signature Analysis $\quad 79$

6.1 Principle of signature analysis $\quad 79$

6.2 Design of signature analyser 81

6.3 Signature analyser tests $\quad 83$

6.4 Summary $\quad 85$

Bibliography $\quad 86$

7 Logic Analyser $\quad 87$

7.1 Role of logic analyser $\quad 87$

7.2 Display facilities $\quad 88$

$\begin{array}{ll}7.3 \text { Logic analyser design } & 93\end{array}$

7.4 Proprietary logic analysers 94

Bibliography 95

8 In-circuit Emulator $\quad 96$

8.1 Development system 96

8.2 MDS software $\quad 98$

8.3 In-circuit emulator facilities 101

8.4 In-circuit emulation using the Philips MDS 101

Bibliography 105

9 Typical VDU Design 106

9.1 VDU operation 106

9.2 Hardware - circuit diagram 106

9.3 Software - control program 110

9.4 Exercises 115

10 Typical Printer Design 117

10.1 Printer operation $\quad 117$

10.2 Hardware - circuit diagram 118

10.3 Software - control program 121

10.4 Exercises 126

11 Typical EPROM Programmer Design 128

11.1 EPROM programming $\quad 128$

11.2 Hardware - circuit diagram 128

11.3 Software - control program 133

$\begin{array}{ll}11.4 \text { Exercises } & 137\end{array}$ 
12 Typical DVM (Digital Voltmeter) Design 139

12.1 DVM operation 139

12.2 Hardware - circuit diagram 139

12.3 Software - control program $\quad 142$

12.4 Exercises 148

13 Typical Bootstrap Loader Design 149

13.1 Role of bootstrap loader 149

13.2 Hardware - circuit diagram 149

13.3 Software 152

13.4 Exercises 156

Bibliography 157

14 Input/output Systems 158

14.1 Introduction 158

14.2 Input/output multiplexing $\quad 158$

14.3 Polling versus interrupts 163

14.4 Interrupt multiplexing 163

14.5 DMA (Direct Memory Access) 166

15 PC Architecture 172

15.1 Introduction 172

15.2 Evolution of the PC 172

15.3 Memory usage 175

$\begin{array}{ll}15.4 \text { Cache memory } & 179\end{array}$

15.5 Numeric co-processor $\quad 180$

Bibliography 183

Appendix A: Microprocessor Data Sheets $\quad 184$

Appendix B: Pin Functions of TTL Digital Integrated Circuits 200

Appendix C: ASCII Character Set 214

Appendix D: Examples (for Chapters 1 to 8-Fault-finding) 216

Glossary 220

Index 231 


\section{Preface}

Microcomputers vary from single-chip systems, such as pocket calculators, through to industrial controllers and multi-user office computers. This rapidly proliferating range of applications has brought with it a requirement for a greater understanding of this new electronic technology and for the acquisition of new skills by servicing personnel. This book is an attempt to describe the procedures and test equipment that can be applied when fault-finding on microprocessor-based equipment. There are few texts that attempt such a comprehensive coverage of this topic, and this book introduces some novel and innovative approaches to microcomputer fault detection.

Chapter 1 reviews the principles of microcomputer operation, while Chapters 2 to 8 describe items of test equipment and fault-finding procedures. The remaining chapters present a series of application studies of typical microcomputer systems which should help to give the reader an understanding of formal design procedures and servicing requirements. Appendixes describe the functions of all microprocessors and their supporting devices, while a Glossary explains the new technical vocabulary that is associated with the modern world of electronics and microcomputers.

In this second edition of the book, Chapter 14 has been added to describe input/output systems in more detail and to introduce advanced computer interfacing arrangements. Chapter 15 presents a review of the familiar IBM PC (Personal Computer) and all its compatible machines, together with descriptions of the architectural features which have been added during the evolution of the PC family. Examples on fault-finding (in Appendix D) have also been added to test the reader's understanding of this important theme within the book.

It is assumed that the reader has an understanding of binary numbers, basic digital electronic circuits and the use of standard electronic test equipment, for example the CRO (oscilloscope). The material presented supports the maintenance topics in BTEC and City and Guilds servicing courses. Additionally, practising service engineers and technicians should find the descriptions of great benefit. Even the computer hobbyist may be able to use the procedures to locate and eliminate faults causing total system failure or partial downgrading. 


\section{Acknowledgements}

The data sheets in Appendix B are reproduced, with permission, from copyright material of RS Components Ltd, Corby, Northants. 